\title{
Vitalii Ivanovich Stafeev (on His 80th Birtday)
}

PACS numbers: $01.60 .+\mathrm{q}$

DOI: $10.1134 / \mathrm{S} 1063782609010254$

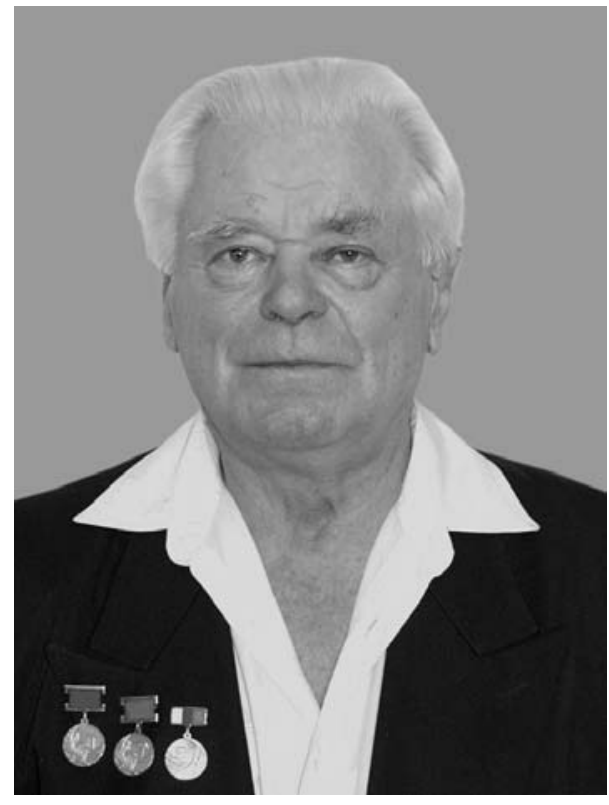

Professor Vitalii Ivanovich Stafeev celebrates his 80th birthday and 55th year of scientific activity on January 1,2009 . He is an outstanding scientist, Honored Scientific Worker of the Russian Federation, and a Doctor of Physics and Mathematics.

Stafeev graduated from physics-mathematics faculty of Kazakh State University (Alma Ata) in 1952. Assigned to Physicotechnical Institute of the USSR Academy of Sciences (in Leningrad), he joined the team of those who laid the foundation for the physics and technology of semiconductor devices. Stafeev was involved in the development and fabrication of the first high-current germanium rectifiers. His activity in this field was acknowledged by his first Government Award and laid foundation for the development of high-power semiconductor electronics in USSR. From the very start, Stafeev demonstrated deep insight into the physics of electronic phenomena in semiconductor devices, which helped him to develop the new principles of their operation, functional logic circuits, and devices for processing and reproduction of images. The multifaceted nature of Stafeev's personality manifested itself in a wide scope of various fields in scientific-teaching and scientific-research activity. In 1964-1969, Stafeev was the Director of the Lukin Research Institute of Physical Problems (Microelectronics Scientific Center, Zelenograd); since 1969, he was, sequentially, a department head, section head, and a head engineer in the field of array photodetectors at the Research Institute of Applied Physics (now the Federal Unitary Enterprise, Research Association Orion); since 1965, Stafeev has been a professor at the Moscow Physicotechnical Institute. He was awarded the state of Honored Worker of the Armaments Industry.

Stafeev greatly contributed to the development of research in the field of narrow-gap semiconductors and infrared photodetectors in this country. Under his guidance, scientific symposia and workshops were convened in this field in various regions of the USSR over a number of years, which ensured the formation of new scientific teams in the USSR (Russia) and in neighboring countries. His students include 25 doctors of science. Stafeev is the author/coauthor, creator/cocreator of 12 monographs and more than 600 publications and inventions. Many results of his studies were included in Soviet and foreign monographs and textbooks.

Stafeev contributed greatly to the development of microelectronics in the USSR; he was the chairman of the Interdepatmental Coordination Council on Microelectronics, the organizer and chair of the faculty of Microelectronics at the Moscow Physicotechnical Institute, and the head of the Microelectronics Section in the Council on Semiconductor Physics at the Presidium of the USSR Academy of Sciences.

Stafeev's research activity has been acknowledged by two State Awards of USSR (in 1982 and 1988) and by the State Award of the Russian Federation (2000).

We congratulate Stafeev on this memorable event and wish him good health and further success in his creative activity.

Zh. I. Alferov, A. L. Aseev, A. A. Gippius, Yu. V. Gulyaev,
V.I. Ivanov-Omskii, O. M. Krokhin, A. A. Kaplyanskii,
M. G. Mil'vidskii, Yu. K. Pozhela, Ya. E. Pokrovskii,
R. A. Suris, A. M. Filachev;
Editorial Board of the journal Fizika I Tekhnika Polu-
provodnikov;
colleagues and friends

Translated by A. Spitsyn 